\begin{tabular}{l|c|c|}
\hline DE & DE GRUYTER \\
OPEN & ECONOMIC THEMES (2016) 54(2): 195-216 \\
& DOI 10.1515/ethemes-2016-0010
\end{tabular}

\title{
RESEARCH AND DEVELOPMENT INVESTMENT AS DETERMINANT OF INTERNATIONAL COMPETITIVENESS AND ECONOMIC GROWTH IN EU28 AND SERBIA
}

\author{
Jelena Vasić
}

Chamber of Commerce and Industry of Serbia, Serbia

\jelena.vasic@yahoo.com

\section{Nataša Kecman}

Chamber of Commerce and Industry of Serbia, Serbia

$\square$ n_kecman@yahoo.com

\section{Igor Mladenović}

\section{University of Nis, Faculty of Economics, Republic of Serbia} $\bowtie$ igor.mladenovic@eknfak.ni.ac.rs

UDC

330.354:33

$0.322(497.1$

1:4-627EU)

Review

paper

Received 21.02.2016. Accepted 18.05.2016.

\begin{abstract}
R\&D expenditures (R\&D) are an important precondition for the economic growth and development, as well as for the improvement of export performances and competitiveness of national economies. Knowledge has been increasingly identified as the primary factor of economic growth in the modern business environment. In order to outline appropriate policy on $R \& D$ expenditures, it is necessary to analyse indicators of the dynamics and quality of $R \& D$ expenditures as well as indicators regarding growth and development of national economies. In this paper, we present $R \& D$ expenditures of old and new EU Member States as well as Serbia. Based on the correlation intensity of indicators of R\&D expenditures and economic growth and export, it's been analysed if R\&D intensity has an impact on competitiveness and growth in mentioned countries since 2000. Although Serbia has implemented significant economic reforms since 2000 and there has been an overall awareness of the need on higher $R \& D$, the $R \& D$ sector still lags behind developed countries of the EU. Therefore, this paper directs attention to the importance of identifying and implementing a national policy on R\&D expenditures, with special focus on necessity for improved R\&D funding of the business sector and growth of R\&D funding from abroad.
\end{abstract}

Keywords: R\&D expenditures, GDP, competitiveness, export, transition countries, EU, technological development, Serbia

JEL classification: $\mathrm{O} 11$ 


\section{Introduction}

Knowledge, in the broadest sense, is recognised as the key factor of growth and prosperity during the process of globalisation and increasingly keen knowledge competition. At the European Council meeting in March 2000, in Lisbon, the EU established a strategic objective for the first decade of $21^{\text {st }}$ century: "to become the most competitive and dynamic economy in the world, based on knowledge and capable of sustainable economic growth with more and better quality jobs and stronger social cohesion” (European Parliament, 2000). Two years later, at the Council meeting in Barcelona, the specified aim was the pursuit of achieving the participation of spending on R\&D of 3\% of GDP by 2010, two thirds of which should be provided by the private sector.

The current EU strategy, Europe 2020, also highlights the importance of R\&D, through the redefinition of investments at the level of the 3\% of EUs GDP, as a target for public and private R\&D investments. Smart EU growth should also be enabled by the Innovation Union, one of the seven Unions' initiatives, whose implementation will meet the objectives defined in the document Euope 2020.

In 2007, the USA brought the Act America competes ${ }^{1}$ for investments in innovations through $\mathrm{R} \& \mathrm{D}$ and improvement of the USA competitiveness (downloaded on January 9, 2016 from: https://www.govtrack.us/congress/ bills/110/hr2272/text), which has subsequently been amended several times, and adjusted in order to better respond to changing circumstances.

The R\&D importance was recognised in Serbia, by the adoption of the Strategy of Scientific and Technological Development of the Republic of Serbia for the period 2010-2015, which provided that "the allocations for science, besides the infrastructure, reach 1\% of GDP, by 2015” (link: http://www.gs.gov.rs/lat/strategije-vs.html). Draft of the Strategy of Scientific and Technological Development of the Republic of Serbia for the period 20162020 - "Research for Development"sets as aim the level of investments at 1.5\% of GDP by 2020 (http://www.mpn.gov.rs/wp-content/uploads/2015/08/ Strategija-nauka-za-inovacije-17-NOVO.pdf.).

OECD has published two manuals, in order to better facilitate observations and analyses of the R\&D and innovation activities (Frascati Manual and Oslo Manual), and established definitions of these terms, which are now widely accepted in the world. "Research and experimental development (R\&D) comprise creative and systematic work undertaken in order to increase the stock of knowledge - including knowledge of humankind, culture and society - and to devise new applications of available knowledge." (OECD, 2015, p. 44).

\footnotetext{
1 "America competes" as the acronym of "America Creating Opportunities to Meaningfully Promote Excellence in Technology, Education, and Science Act."
} 
R\&D investments are an important prerequisite for economic growth and development in the world, as well as improving the export performance of national economies. Gross fixed capital formations, which represent a comprehensive aggregate investment at the national economy level, are much more volatile than GDP trends. Their movement is more volatile, compared to other macroeconomic aggregates, considering that in the recession period they are reduced and during economic growth increased, at higher rates. At the global level, gross investment amounted to about 23\% of GDP, in the period 2000-2013 (UNCTADstat, 2016). Serbia achieved an average of $13.9 \%$ of GDP in the period 2000-2013, with average annual growth of $6.4 \%$. Serbian Gross investments in intellectual property, during the aforementioned period, recorded the annual growth of $8.1 \%$, with realised average share in GDP of $1.9 \%$, which was the lowest in 2000 (1.06\%), and highest in $2008(2.09 \%){ }^{2}$

R\&D investments in Serbia, in 2014 amounted to EUR 256.0 million, according to Eurostat, while the average investment per country in the new EU member states (EU13) amounted to EUR 935.0 million and in the old EU member states (EU15) amounted to EUR 18.1 billion.This research paper focuses on the old (EU15) and new (EU13) EU member states and Serbia. All EU28 member states are, in this research paper, divided in two groups: (1) EU15 - old EU28 member countries (Austria, Belgium, Greece, Denmark, Ireland, Italy, Luxembourg, Germany, Portugal, United Kingdom, Finland, France, the Netherlands, Sweden and Spain); (2) EU13 - new EU28 member countries which joined EU in the period after 2004 (Bulgaria, Estonia, Cyprus, Lithuania, Latvia, Malta, Hungary, Poland, Romania, Slovakia, Slovenia, Croatia and Czech Republic). R\&D investments in Serbia, during six-year period 2009-2014, ranged from 0.71\% GDP (2011) to 0.91\% GDP (2012), while the average share reached $0.79 \%$ GDP, for the same period (Eurostat database for Serbia covers annual data for period from 2009). According to that indicator, Serbia is lagging behind compared to the EU28 average (1.99\%). ${ }^{3}$ Besides the unfinished transition process, the global economic crisis has further limited allocations for $R \& D$ that have slowed down after 2009. However, R\&D expenditures at the EU28 level were significantly lower than the 3\% of GDP target.In Serbia, the country with transition period longer than twenty years and whose completion is expected by entering into the EU, there is awareness of the necessity of increasing R\&D expenditures. In addition, there is a need for more efficient involvement of all sectors in the R\&D investment, at the level of the national economy. Also, it emphasises the need of larger Business enterprise R\&D expenditures and boosting R\&D expenditures from abroad.These

\footnotetext{
${ }^{2}$ Authors' calculations based on data Statical Office of the Republic of Serbia (SORC) Link: http://webrzs.stat.gov.rs/WebSite/public/ReportView.aspx.

${ }^{3}$ R\&D investments in old EU15 member countries amounted to 2.08\% of GDP,and in these new EU13 member countries to about 1.0\% of GDP, in the period 2009-2014.
} 
guidelines were the research paper basis, with aim to find answers to the question whether the intensity of R\&D investment has had an impact on competitiveness and economic growth in the transition period since 2000. The analysis covers the period until 2014, with regard to available indicators in the international base data for the Republic of Serbia. However, some indicators have been available since 2009. The aim of the research is to point out the particularity of R\&D investments and focusing on the necessary models of further increasing and productive sectoral guidance of R\&D expenditure allocations in Serbia.

\section{A Literature Review on the Impact of R\&D Investments on the Selected Macroeconomic Variables Development}

The theoretical and empirical literature has shown that R\&D investments are crucial for economic growth and export increase, and that the connection is bidirectional. The literature on growth theory can be divided into three categories, according to which growth factors highlights. The Harrod-Domar growth model stresses the importance of savings and investments, neo-classical models of economic growth point to technical progress as the leading factor of growth and new growth theories (endogenous growth theories) indicate the importance of the R\&D, the accumulation of knowledge and externalities (Lykogianni et al., 2008). At the beginning of the twentieth century, Joseph Schumpeter pointed out that innovations were the most important feature of the capitalist economy. By the 1950s Robert Solow developed methods to quantify the sources of growth.It was noted that technological changes accounted for more than half of the registered growth, increasing labour productivity and national income. The neoclassical growth model of the Nobel laureate Robert Solow (Solow, 1956, pp. 65-94) is one of exogenous growth models, given that technological progress is exogenously determined factor of economic growth. On the other hand, all models which contained technological advances as the explanatory variable of economic growth are called endogenous growth models. Leading researches in this group of models are works of Romero $(1986,1990)$ and Lucas (1988, pp. 3-42) that formulate models of growth with technological progress, which is not an exogenous variable.

Empirical data have shown that there are significant differences in the level of living standards between developed and developing countries, as well as that the stable economic growth rates are realised only in developed countries, while developing countries are faced with significantly uneven interannual economic growth (with periods of economic stagnation and recession). Endogenous growth models, developed in 1980s, were faced with numerous problems that made it impossible to test the connection between $R \& D$ investments and economic growth. However, a number of studies have shown that stable 
economic growth associated with savings and investments (in capital and labour force), as well as educated workforce can provide bridging of the technological gap with respect to countries that are in the technological lead. Studies have shown that the export oriented economies and stable business conditions are associated with economic growth.

Theoretical models have shown that R\&D investments initiate economic growth, which is the reason for the active role of government in achieving the optimal level of these investments. Empirical research (Grilicher, 1992) stressed the importance of R\&D investments and positive impact on more than half of the growth of output per capita, while Jones and Williams (Jones and Williams, 1998) pointed out that necessary optimal $R \& D$ investment level was at least four times higher than the invested amount in 1998 for that purpose. In addition, R\&D investments provide significant social contribution (positive externalities), and therefore are the key component of economic growth and development.

Interdependence of $R \& D$ investmens and export have been the research focus of numerous studies. The two leading theoretical models, study the relationship between $R \& D$ and exports, but in the direction of the $R \& D$ investments impact on export growth. All studies are based on the view that the $\mathrm{R} \& \mathrm{D}$ inputs create new products and production processes. At the same time, the process of specialisation and competitive advantage creating are based on production factors input (labour force, materials, capital and technology). The authors from University of Nottinghem (Grima et al., 2007) have studied twoway connection between exports and innovations of Ireland and the United Kingdom.They have noted that previous export experience strengthens the companies' innovation capacity, which was reflected in the increased R\&D activities, in the case of Ireland. The influence of the export markets' development level is particularly emphasised, since sustaining of the competitiveness in developed markets, and survival in the markets that have sophisticated requirements, additionally stimulate export companies to invest in $\mathrm{R} \& \mathrm{D}$ in order to improve the quality of its processes, products and services. The study which also explored the same interdependence for companies from Taiwan (B. Yan Aw et al, 2008) also points to the positive impact of exports and R\&D investments to the increase of productivity.

The Ex-Post Evaluation of the effects of the $7^{\text {th }}$ EU Framework Programme for R\&D ${ }^{4}$ (High Level Expert Group, 2015), estimated that during the course of

\footnotetext{
${ }^{4}$ The $7^{\text {th }}$ EU Framework Programme for R\&D (FP7) in the period 2007-2013. represented the main EU instrument for R\&D funding and the extablishment the European Research Area. The EU has a long tradition of framework programs for research, which has lasted forover 30 years. With a total budget of almost EUR 56 billion, FP7 has provided the funds required for the implementation of about 25,000projects.
} 
this program, the investments in R\&D were worth a total of EUR 90 billion (of which the EU grants amounted to EUR 50 billion, while own resources of program participants to additional EUR 40 billion). The indirect effects on the business enterprise sector were estimated at a totalof additional EUR 500 billion, over the next 25 years. In the field of newly opened jobs, FP7 directly provided opening of 130,000 new jobs in the $R \& D$ sector, during the 10 years of the projects' implementation, respectively, an additional 160,000 indirect jobs over the next 25 years. Small and medium-sized enterprises, participants of the "Cooperation" segment FP7, showed an average turnover increase of 22\%, growth of number of employees of $25 \%$ and export growth of $28 \%$.

Study conducted for the purpose of making of the Western Balkans Regional Strategy on R\&D for Innovation (World Bank, 2013), found that reaching the R\&D investment level of 3\% GDP in Croatia would ensure GDP growth of $6 \%$ and increase in exports of $13 \%$.

\section{The Transition Process and the Global Economic Crisis Impact on R\&D Funding}

R\&D investment at the national economy level largely depends on economic development. Although in Serbia, since 2000,comprehensive social and economic reforms have been implemented in order to create a favourable business environment, the R\&D sector still lags behind EU member states. Transitional business conditions limit the optimal R\&D investment level, which determines economic growth to be based on technological processes on the lower level of development. As a consequence, Serbian export is dominated by lower phase processing products and raw materials. Comparison with the benchmark Central and Eastern European countries shows that there is slower progress in the transformation of domestic production and export structure towards products that require innovative technologies as well as specialized and highly qualified workforce. The Global economic crisis has further had a negative impact on business conditions and investment research and development activities in the country.

Within the EU statistical system, a wide range of technological development indicators and measurements of R\&D investments ${ }^{5}$ have been developed. The most commonly used indicator is the share of R\&D expenditures in GDP, as well as R\&D expenditures expressed in purchasing power standards, abr. PPS. ${ }^{6}$

\footnotetext{
${ }^{5}$ Detailed overview of all indicators in the Eurostat database can be downloaded at the following link: http://ec.europa.eu/eurostat/data/database.

${ }^{6}$ Gross R\&D expenditures are expressed in purchasing power standards, in million units (Million PPS - purchasing power standard). PPS are a fictive currency unit that eliminates differences in purchasing power i.e. different price levels, between countries.
} 
R\&D intensity is expressed through Gross R\&D expenditures as a share of GDP, in percentages. These data cover the period since 2000, for EU member countries. Data for Serbia are available for the period 2009-2013. Besides R\&D intensity, as the measurement of $R \& D$ investment the structure of $R \& D$ expenditures by funding sectors is used, as well as by sectors which realise $\mathrm{R} \& \mathrm{D}$ process.

Total R\&D investments at the EU28 level were increased by $65 \%$, in the period 2000-2014, from EUR 171.2 billion to EUR 283.0 billion. Despite the growth in total R\&D investments presented in absolute terms, the new EU member states (EU13) continue to have a negligible share in total expenditure at the EU28 level: from the initial $2 \%$ in 2000, this participation increased to $4.3 \%$ of total EU28 level investments in 2014.

The old EU member states (EU15) have a stable R\&D investment structure, dominated by Business enterprise sector investments. During the 2000-2013 period, the business enterprise sector financed about 55\%of R\&D investments, while the Government sector share has declined slightly from 34\% to 32\%. The higher education sector's share and private non-profit sector's share are negligible, while a slight increase in the abroad sector participation has been recorded, from $7 \%$ in 2000 to $10 \%$ in 2013.

Contrary to the old member EU states, the structure of R\&D funded sectors in the new EU member states (EU13) has undergone significant changes in the period after 2000. Namely, the Government sector share gradually decreased, from 53\% in 2000 to $39 \%$ in 2014. On the other hand, a significant growth was recorded of the abroad sector participation, which increased almost five times, from $4 \%$ in 2000 to $19 \%$ in 2013 . The share of the other three sectors remained unchanged. It could be better seen on the following chart, which presents the movements of the structure of $R \& D$ investments by sector funding, in the period 2000-2013.

Comparing the developed economies of Japan and the USA, the following graph shows that the highest R\&D intensity has Japan (average share amounts to 3.28\% of GDP in the period 2000-2012), then the next largest share has been realised in the USA (average share of 2.65\% GDP in the period 2000-2012). Average realises the share of Gross R\&D investment in GDP at the EU28 level stood at $1.87 \%$ GDP. The average share of Gross R\&D investment in GDP at the EU15 level, amounted to 1.95\% GDP, and at EU13 level 0.8\% GDP, in the same period. The average realised share of Gross R\&D investments in Serbia, according to the available data for the six-year period 2009-2014, amounts to $0.79 \%$ of GDP. 
Figure 1 The structure of total intramural R\&D expenditure, by source of funds, EU13 and EU15, for period 2000-2013

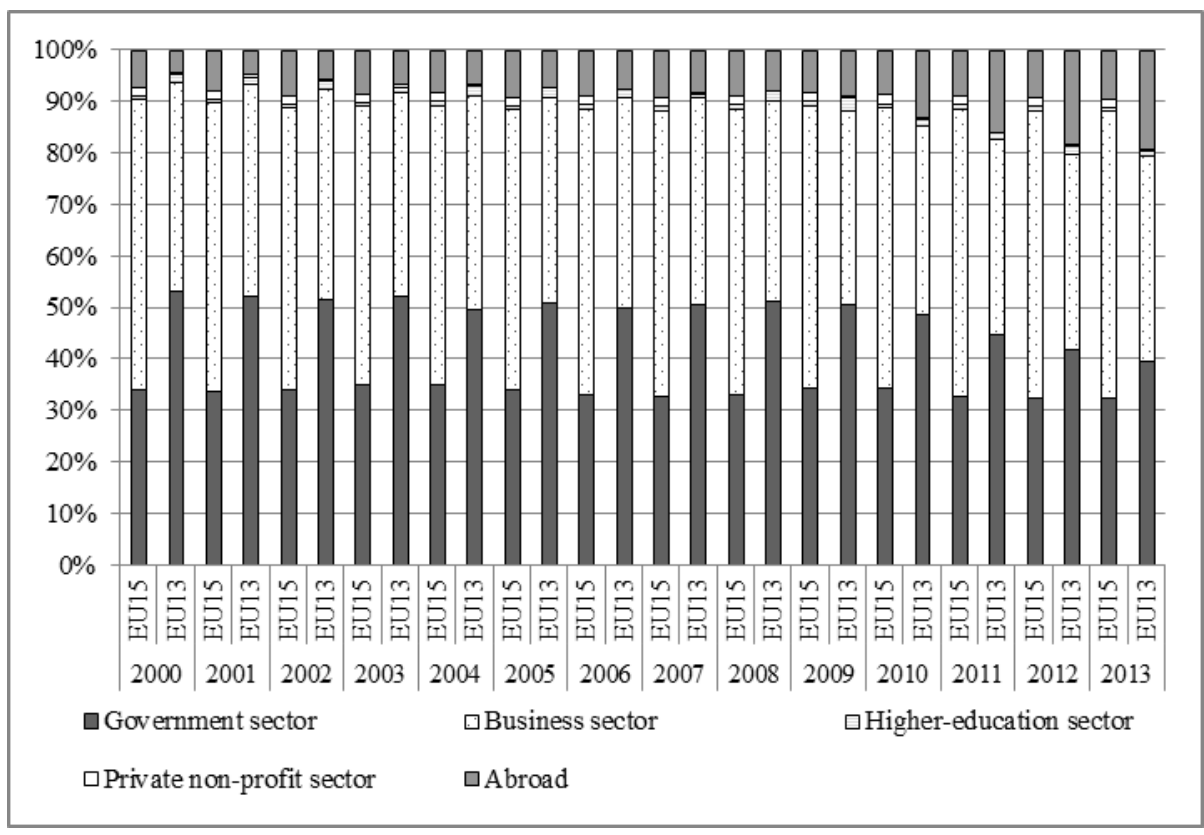

Source: Authors' calculations based on Eurostat data.

Havas et al. (2015, p. 10) pointed out that the R\&D systems in ten Central and Eastern Europe countries, EU memebers, ${ }^{7}$ were characterised by „highly centralised, politically controlled academic sector, with a limited (or hardly any) autonomy in certain fields of investigations, especially in social sciences and humanities, and a rigid division of labour between universities, focussing mainly on teaching, on the one hand, and instituties of the Academies of Sciences, almost exclusively performing research, on the other.“

The process of transformation of the R\&D in former socialistic countries, now EU members, and their approach to the frame defined by the model of the Western European countries show a different pace of reforms. According to Lepori et. al (2009), the abandonment of the communist R\&D policy, common to all Eastern block countries, is only the first step of reforms while the next transition phase vary due to the specifics of each country.

\footnotetext{
${ }^{7}$ The included countries are: Bulgaria, Estonia, Lithuania, Latvia, Hungary, Poland, Romania, Slovakia, Slovenia and Czech Republic.
} 
Figure 2 R\&D intensity (Gross R\&D investments, as \% of GDP), in EU15, EU13, USA, Japan and Serbia, the period 2000-2014

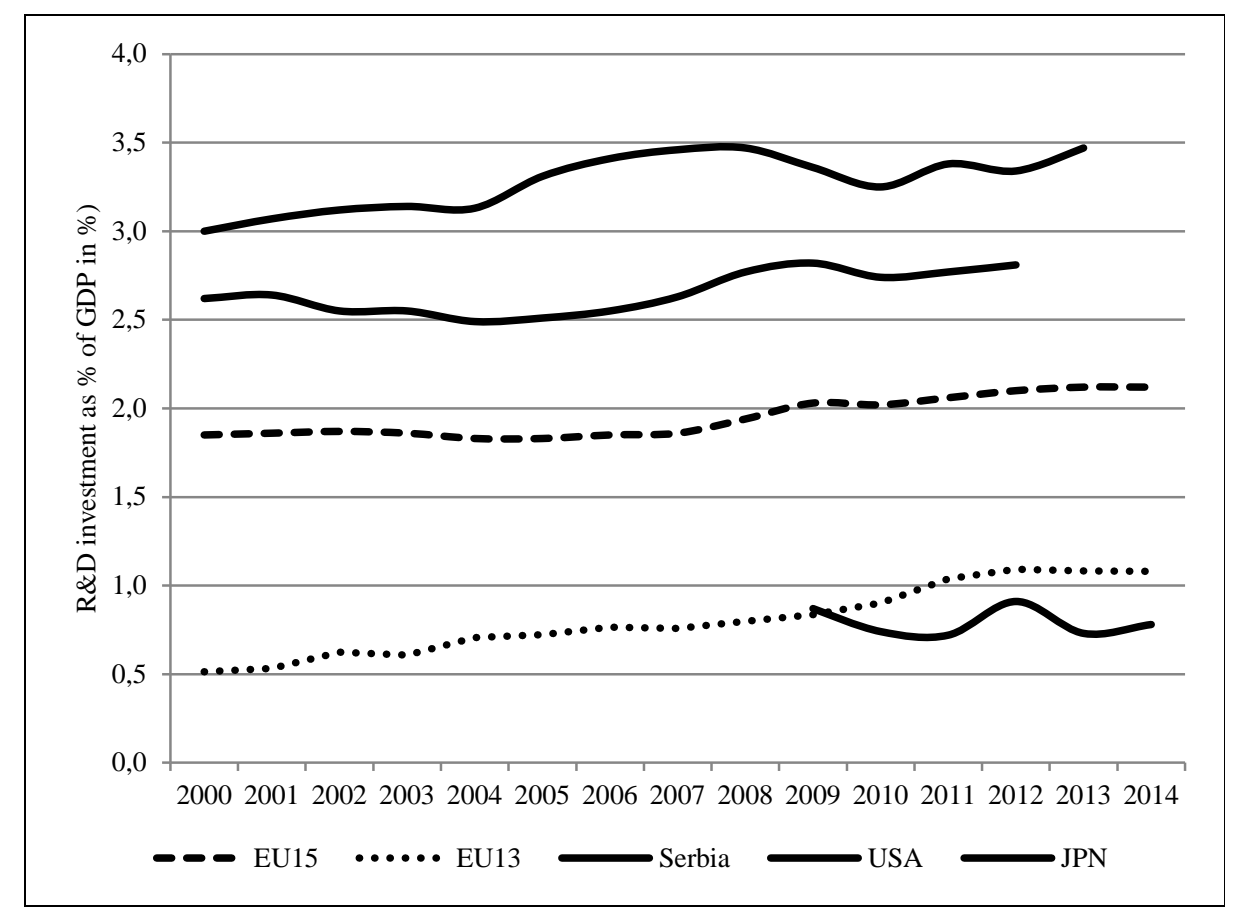

Source: Authors' calculations based on Eurostat data.

That conclusion is confirmed by the analysis of the structure of R\&D investments during the period 2000-2014, for the selected countries. ${ }^{8}$

In the old EU member states, the abroad sector recorded a significant growth in the R\&D investments structure in Finland, where the insignificant $2 \%$ in 2000 increased to more than $17 \%$ in 2014, which allowed a proportional reduction of the business enterprise sector's share.On the other hand, the participation of the abroad sector in R\&D funding in Austria sightly decreased in the reported period, whereas previously equal participation of the Government sector and the business enterprises sector was changed in favour of the enterprise sector.

Both observed southern EU old member states, which are facing the devastating effects of the global economic crisis, characterised by a dominant Government sector's funding share in R\&D investments. Unlike Greece, where

\footnotetext{
${ }^{8}$ Different criteria for selection of countries were implemented: a similar number of inhabitants compared to Serbia (Austria, Finland, Slovakia, Bulgaria), heritage of once uniform former R\&D system (Slovenia, Croatia) and southern old EU member countries affected by Global economic crisis (Greece i Portugal).
} 
the Government sector's share even increases over time, in Portugal there is a decrease of Government sector's share and a significant increase in Business sector enterprises' share. During 2007-2008, Portugese companies financed almost half of the total $R \& D$ expenditures.

Bulgaria and Slovakia, ex-Eastern Block countries, which are new EU member states with similar population as Serbia, record very dynamic R\&D Abroad funded investment growth. The share of the abroad sector, in these countries, with a few insignificant percent in 2000 rose until the end of the review period to a quarter of all R\&D investments in Slovakia, or half of all R\&D expenditures in Bulgaria. However, the transformation of R\&D systems of these countries developed in different directions: during the first decade of XXI century Bulgaria had an unchanged financing structure of R\&D, which was dominated by the Government sector's funding. The reversal occurred in 2010, when the share of the abroad sector's recorded growth from $10 \%$ in the former year to $40 \%$ of all R\&D investments. The abroad sector's funding growth was accompanied by a decrease in participation of the Government sector, but also a decrease in the business enterprise sector. On the other hand, in Slovakia, the business enterprise sector's funding accounted for $55 \%$ of total R\&D investment funds in 2000 and dropped to 32\% in 2014. Government sector's funding growth, which rose to $41 \%$ offset it.

Slovenia and Croatia are two countries that emerged on the foundations of Yugoslavia, represent an example, bearing in mind the legacy of the identical R\&D system. Croatia is characterised by a very similar level of $R \& D$ investment funds of the Government and business enterprise sectors, if compared 2002 and 2014, given that at the start of this period, both sectors accounted for $46 \%$ of total R\&D investments, but at the end of this period their share dropped to $43 \%$ and $42 \%$, respectively. The biggest difference was recorded in the abroad sector, which increased from negligible $1.5 \%$ in 2002 to almost 13\% of total R\&D investment in 2014.

On the other hand, Slovenia could be presented as an example of a country, which rapidly transformed its R\&D system and has become closer to highly developed countries according to the investment in science. Namely, during 2000, Slovenian companies financed more than half of the total R\&D expenditures, more precisely 53\%, while the Government sector share was $40 \%$. Over the time, the share of the private non-profit sector slightly increased as well as the higher education sector, while the most significant changes were observed in the participation of the Government and Business enterprises sectors in 2014 (the Slovenian business enterprise sector has secured 68\% of the R\&D funds, while the Government sector's share fell to 22\%).

The R\&D investment structure in Serbia has a specifity that has not been observed in the other countries: the higher education sector is normally 
negligible as a source of R\&D funds, but in Serbia it contributes as much as $34 \%$ of the total R\&D investments (according to the data for 2012). During the observed six-year period 2009-2014, the share of the Business-enterprise sector didn't exceed 9\%, while the share of the abroad sector increased from $7.2 \%$ to $12 \%$.The dominant source of funding for Serbian science in all observed years was the Government sector, which decreased during time, but still retained more than a half share. If we assume that High education sector R\&D is largely implemented at state colleges and institutes, we can conclude that the public sector (government sector and higher education in state ownership) accounted for about $80 \%$ of the overall allocations for R\&D in Serbia. Starting from the objective defined in Barcelona in 2002 at a meeting of the Council, according to which the private sector should provide two thirds of the funds needed for $R \& D$, it can be considered that the structure of $R \& D$ financing funds in Serbia is unfavourable and that, as such, certainly does not encourage the growth of GDP and doesn't contribute to dinamisation of exports.

The share of five R\&D funded sectors has been shown at the following chart. According to Eurostat data, those sectors are Business enterprise sectors, Government sector, High education sector, Private non-profit sector, and abroad activities. The participation of the private and government sectors is dominant, withgrowth of the abroad sector activities in recent years in the EU13.

Table 1 Share of the total intramural $R \& D$ expenditure, by source of funds: 2000, 2009 and 2013

\begin{tabular}{|c|c|c|c|c|c|c|}
\hline \multirow{2}{*}{ Theritory: } & EU15 & EU13 & SR & EU15 & EU13 & SR \\
\hline & \multicolumn{3}{|c|}{ Business enterprise sector (\%) } & \multicolumn{3}{|c|}{ Government sector (\%) } \\
\hline 2000 & $56 \%$ & $40 \%$ & $8 \%$ & $34 \%$ & $53 \%$ & $63 \%$ \\
\hline 2009 & $55 \%$ & $38 \%$ & $9 \%$ & $34 \%$ & $51 \%$ & $63 \%$ \\
\hline \multirow[t]{2}{*}{2013} & $56 \%$ & $40 \%$ & $8 \%$ & $32 \%$ & $39 \%$ & $60 \%$ \\
\hline & \multicolumn{3}{|c|}{ Higher-education sector (\%) } & \multicolumn{3}{|c|}{ Private non-profit sector (\%) } \\
\hline 2000 & $1 \%$ & $1 \%$ & $21 \%$ & $2 \%$ & $0,4 \%$ & $1 \%$ \\
\hline 2009 & $1 \%$ & $3 \%$ & $22 \%$ & $2 \%$ & $0,3 \%$ & $0,1 \%$ \\
\hline \multirow[t]{2}{*}{2013} & $1 \%$ & $1 \%$ & $25 \%$ & $2 \%$ & $0,2 \%$ & $0 \%$ \\
\hline & \multicolumn{3}{|c|}{ Abroad sector (\%) } & & & \\
\hline 2000 & $7 \%$ & $4 \%$ & $7 \%$ & & & \\
\hline 2009 & $8 \%$ & $9 \%$ & $5,5 \%$ & & & \\
\hline 2013 & $10 \%$ & $19 \%$ & $7,8 \%$ & & & \\
\hline
\end{tabular}

Source: Authors' calculations based on Eurostat data. 
The competitiveness of a national economy is presented by assessment of the results achieved in the field of innovation. Serbia's position is enhanced by the SII indicator (Summary Innovation Index), which in 2014 reached 69\% of the EU average (PRO-INNO Europe Innovation Index, 2015). By that, Serbia on the list of European non-EU28 member countries, held a position after Norway, as a country that is modest innovative (PRO-INNO Europe Innovation Index, 2015). According to this indicator, Serbia has a higher position than Hungary, Greece, Slovakia, Croatia, Poland, Lithuania, Latvia, Turkey, Bulgaria, the Republic of Macedonia and Romania. The assessment is that the performance of Serbia is positive in the field of youth education, investment in innovations that are not only R\&D and employment in Knowledge-intensive activities. Serbian innovation performances were significantly improved in the period 2007-2014, at an annual growth rate of 6.3\% (PRO-INNO Europe Innovation Index, 2015, p. 31).

The following table shows the contribution of the leading sectors' allocations for R\&D and gap in comparison to two leading economies in the world, Japan and the USA. The business-enterprise sector has the greatest contribution in Japan (2.5\% of GDP). In Serbia, the business-enterprise sector's contribution amounted to $0.14 \%$ of GDP. ${ }^{9}$ On the other hand, the contribution of the Government sector is the largest in the USA, reaching $0.32 \%$ of GDP, while the lowest in the EU13 (0.18\% of GDP). The largest gap was achieved at the level of overall R\&D intensity between Japan and the EU13, the businessenterprise sector funding between Japan and Serbia and the Government sector funded between USA and EU13.

Table 2 Contribution of the leading sectors (business sectors and government) to $R \& D$ investments allocations and the gap with the USA and Japan (Average for 2000-2014)

\begin{tabular}{|l|c|c|c|}
\hline \multirow{2}{*}{ Sectors: } & $\begin{array}{c}\text { R\&D } \\
\text { intensity }\end{array}$ & $\begin{array}{c}\text { Business enterprise } \\
\text { sector R\&D intensity }\end{array}$ & $\begin{array}{c}\text { Government } \\
\text { sector R\&D } \\
\text { intensity }\end{array}$ \\
\cline { 2 - 4 } & \multicolumn{3}{|c|}{ (R\&D intensity, as \% of GDP) } \\
\hline EU15 & 1,95 & 1,24 & 0,24 \\
\hline EU13 & 0,80 & 0,39 & 0,18 \\
\hline SR $^{*}$ & 0,79 & 0,14 & 0,25 \\
\hline $\mathrm{SAD}^{* *}$ & 2,65 & 1,85 & 0,32 \\
\hline $\mathrm{JPN}^{* * *}$ & 3,28 & 2,49 & 0,29 \\
\hline \multicolumn{3}{|l|}{} \\
\hline SAD/EU15, gap & 0,70 & 0,61 & 0,08 \\
\hline SAD/EU13, gap & 1,87 & 1,46 & 0,14 \\
\hline
\end{tabular}

\footnotetext{
${ }^{9}$ Note: Average share for Japan was calculated based on data for period 2000-2013, and for Serbia: 2009-2014.
} 
Vasić, Kecman, Mladenović/Economic Themes, 54 (2): 195-216

\begin{tabular}{|l|c|c|c|}
\hline \multirow{2}{*}{ Sectors: } & $\begin{array}{c}\text { R\&D } \\
\text { intensity }\end{array}$ & $\begin{array}{c}\text { Business enterprise } \\
\text { sector R\&D intensity }\end{array}$ & $\begin{array}{c}\text { Government } \\
\text { sector R\&D } \\
\text { intensity }\end{array}$ \\
\cline { 2 - 4 } & \multicolumn{3}{|c|}{ (R\&D intensity, as \% of GDP) } \\
\hline SAD/SR, gap & 1,86 & 1,71 & 0,06 \\
\hline JPN/EU15, gap & 1,33 & 1,25 & 0,05 \\
\hline JPN/EU13, gap & 2,50 & 2,10 & 0,11 \\
\hline JPN/SR, gap & 2,49 & 2,35 & 0,03 \\
\hline \multicolumn{3}{|c|}{} \\
\hline EU15/SR, gap & 1,16 & 1,10 & $-0,02$ \\
\hline EU13/SR, gap & $-0,01$ & 0,25 & $-0,08$ \\
\hline
\end{tabular}

Notes: The gap represents the difference between the R\&D intensity by these territories and sectors.

*Data for Serbia covered period 2009-2014.

**Withouth data for 2013 and 2014.

*** Without data for 2014.

Source: Authors' calculations based on Eurostat data.

Table 3 shows the values of real Gross R\&D expenditures, GDP and the R\&D intensity in 2000 and 2014. At the EU15 level, the R\&D expenditures doubled in Portugal, Ireland, Austria, Spain and Denmark. The highest annual GDP growth in the same period was realised in Ireland, Luxemburg and Sweden.

Among the 13 new EU member states, according to the amount of R\&D funding, Slovenia, the Czech Republic, Extonia and Lithuania stand out. In Estonia (four times) and Lithuania (three times) there was the highest growth of R\&D investments. In Estonia, R\&D allocation was nearly five times higher in 2014, and in Lithuania four times higher compared to 2000. The R\&D intensity in these countries recorded extremely high dynamics during these years with relatively high growth rates. An indicator of the R\&D intensity is obtained by dividing the R\&D investment amount and GDP, expressed in absolute values. It means that in the period when GDP grows faster than R\&D investment R\&D intensity may be slightly reduced. Finland, Austria, Sweden and Denmark are EU countries that have achieved the target set in the Lisbon Strategy. These countries have achieved the highest growth of $R \& D$ investment during the reported period, with the total turnover and GDP growth above the EU15 average. Among the EU13 member states, the intensity of investment is the largest in Slovenia, the Czech Republic and Hungary. Gross R\&D funding was doubled in the reported period, with above average GDP growth compared to the EU13. Comparing the data for Serbia, it was noted that a smaller amount of R\&D in 2014 was set aside compared to 2009, with the GDP growth of 1.7\%. The intensity of R\&D investments declined in Serbia, while in the same period (2009-2014) it was reduced also in only two EU13 countries, Croatia and 
Romania. The largest increase in the R\&D intensity during the period 20002014, was achieved in Estonia and Cyprus.

Table 3 Gross R\&D expenditures, real GDP and R\&D intensities: 2000 and 2014

\begin{tabular}{|c|c|c|c|c|c|c|c|c|c|}
\hline \multirow[t]{2}{*}{ Countries: } & \multicolumn{3}{|c|}{$\begin{array}{c}\text { Gross R\&D expenditures } \\
\text { (GERD) }^{1} \\
\text { (in mill PPS) }\end{array}$} & \multicolumn{3}{|c|}{$\begin{array}{c}\text { GDP }^{2} \\
\text { (in EUR mill) }\end{array}$} & \multicolumn{3}{|c|}{$\begin{array}{l}\text { GERD/GDP ratio }{ }^{3} \\
\text { (in \%) }\end{array}$} \\
\hline & 2000 & 2014 & $\begin{array}{c}\text { Growth } \\
\text { (in \%) }\end{array}$ & 2000 & 2014 & $\begin{array}{l}\begin{array}{l}\text { Growth } \\
\text { (in \%) }\end{array} \\
\end{array}$ & 2000 & 2014 & $\begin{array}{c}\begin{array}{c}\% \\
\text { change }\end{array} \\
\end{array}$ \\
\hline \begin{tabular}{|l|}
$\begin{array}{l}\text { EU15 } \\
\text { (average) }\end{array}$ \\
\end{tabular} & $153.628,175$ & $250.315,151$ & 62,9 & 10.409 .495 & 12.071 .669 & 16,0 & 1.9 & 2.1 & 14.6 \\
\hline Austria & $3.888,302$ & $8.897,105$ & 128,8 & 253.713 & 307.257 & 21,1 & 1.9 & 3.0 & 58.2 \\
\hline Belgium & $4.840,517$ & $8.896,819$ & 83,8 & 311.463 & 377.305 & 21,1 & 1.9 & 2.5 & 27.5 \\
\hline Greece & & $1.787,263$ & - & 189.901 & 185.511 & $-2,3$ & & 0.8 & 25.8 \\
\hline Denmark & $2.997,293$ & $5.902,085$ & 96,9 & 225.405 & 246.598 & 9,4 & 2.2 & 3.1 & 40.6 \\
\hline Ireland & $1.062,144$ & $2.579,874$ & 142,9 & 123.609 & 182.167 & 47,4 & 1.1 & 1.6 & 42.2 \\
\hline Italy & 13.248,591 & $20.691,672$ & 56,2 & 1.556 .221 & 1.535 .331 & $-1,3$ & 1.0 & 1.3 & 27.7 \\
\hline Luxembourg & 336,415 & 515,231 & 53,2 & 30.248 & 43.650 & 44,3 & 1.6 & 1.2 & -21.0 \\
\hline Germany & \begin{tabular}{|l|}
$45.483,871$ \\
\end{tabular} & 79.525,912 & 74,8 & 2.358 .691 & 2.736 .412 & 16,0 & 2.4 & 2.8 & 18.8 \\
\hline Portugal & $1.150,615$ & $2.865,579$ & 149,0 & 167.145 & 169.129 & 1,2 & 0.7 & 1.3 & 79.2 \\
\hline UK & $24.204,918$ & $32.947,952$ & 36,1 & 1.547 .773 & 1.965 .835 & 27,0 & 1.7 & 1.7 & -0.6 \\
\hline Spain & $6.768,837$ & $14.226,112$ & 110,2 & 867.918 & 1.038 .582 & 19,7 & 0.9 & 1.2 & 34.8 \\
\hline France & 28.639,526 & $43.822,008$ & 53,0 & 1.771 .701 & 2.060 .872 & 16,3 & 2.1 & 2.3 & 8.7 \\
\hline Finland & $3.862,204$ & $5.236,491$ & 35,6 & 158.091 & 186.295 & 17,8 & 3.3 & 3.2 & -2.5 \\
\hline Netherlands & $7.875,012$ & $11.969,124$ & 52,0 & 554.727 & 638.476 & 15,1 & 1.8 & 2.0 & 8.8 \\
\hline Sweden & & $10.451,925$ & & 299.664 & 391.187 & 30,5 & & 3.2 & -9.7 \\
\hline \begin{tabular}{|l|}
$\begin{array}{l}\text { EU13 } \\
\text { (average) }\end{array}$ \\
\end{tabular} & $6.861,830$ & $19.907,640$ & 190,1 & $743.633,9$ & $1.092 .533,3$ & 46,9 & 0.5 & 1.1 & 37.5 \\
\hline Bulgaria & 224,621 & 711,440 & 216,7 & 24.427 & 39.507 & 61,7 & 0.5 & 0.8 & 63.3 \\
\hline Czech Rep. & $1.619,24$ & $4.821,319$ & 197,8 & 114.387 & 160.284 & 40,1 & 1.1 & 2.0 & 78.6 \\
\hline Estonia & 70,682 & 382,937 & 441,8 & 10.642 & 17.408 & 63,6 & 0.6 & 1.5 & 143.3 \\
\hline Croatia & & 536,380 & & $23.611,0$ & $43.045,0$ & 82,3 & & 0.8 & -10.2 \\
\hline Latvia & 73,237 & 237,387 & 224,1 & 12.260 & 20.703 & & 0.4 & 0.7 & 54.5 \\
\hline Lithuania & 154,592 & 600,365 & 288,4 & 18.321 & 32.925 & 79,7 & & 1.0 & 29.1 \\
\hline Poland & $2.263,379$ & $6.678,591$ & 195,1 & 246.652 & 403.699 & 63,7 & 0.6 & 0.9 & 46.9 \\
\hline Hungary & 848,743 & $2.523,843$ & 197,4 & 80.425 & 103.769 & 29,0 & 0.8 & 1.4 & 74.7 \\
\hline Malta & & 84,018 & & 5.392 & 7.497 & 39,1 & & 0.9 & 60.4 \\
\hline Cyprus & 28,514 & 94,084 & 230,0 & 14.174 & 17.173 & 21,2 & 0.2 & 0.5 & 104.3 \\
\hline Romania & 406,875 & $1.118,5$ & 174,9 & 86.401 & 138.984 & 60,9 & 0.4 & 0.4 & 5.6 \\
\hline
\end{tabular}




\begin{tabular}{|c|c|c|c|c|c|c|c|c|c|}
\hline \multirow[t]{2}{*}{ Countries: } & \multicolumn{3}{|c|}{$\begin{array}{c}\text { Gross R\&D expenditures } \\
\text { (GERD) }^{1} \\
\text { (in mill PPS) }\end{array}$} & \multicolumn{3}{|c|}{$\begin{array}{c}\text { GDP }^{2} \\
\text { (in EUR mill) }\end{array}$} & \multicolumn{3}{|c|}{$\begin{array}{c}\text { GERD/GDP ratio } \\
\text { (in \%) }\end{array}$} \\
\hline & 2000 & 2014 & $\begin{array}{c}\text { Growth } \\
\text { (in \%) }\end{array}$ & 2000 & 2014 & $\begin{array}{c}\text { Growth } \\
(\text { in \%) }\end{array}$ & 2000 & 2014 & $\begin{array}{c}\% \\
\text { change }\end{array}$ \\
\hline Slovenia & 418,902 & $1.113,764$ & 165,9 & 27.888 & 36.191 & 29,8 & 1.4 & 2.4 & 75.7 \\
\hline Slovakia & 333,914 & $1.005,001$ & 201,0 & 41.895 & 73.162 & 74,6 & 0.6 & 0.9 & 39.1 \\
\hline Years: & 2009 & 2014 & & 2009 & 2014 & & 2009 & 2014 & \\
\hline Serbia & 563.073 & 528.827 & -6.1 & $29,593.3$ & $30,084.2$ & 1,7 & 0.87 & 0.78 & -10.3 \\
\hline
\end{tabular}

Notes: Annual GDP growth is calculated on the basis of data on the GDP in market prices, Chain linked volumes (the reference year 2010).

1)Gross R\&D expenditures expressed by Purchasing Power Standards, in million PPS. PPS are fictive "currency" unit which eliminates differences in purchasing powerbetween countries.

2) GDP expressed in EUR million, in market prices, Chain linked volumes (the reference year 2010).

3) R\&D intensity.

4) The annual GDP growth in period 2000-2014,except for countries without available data series. National statistic data used for Croatia.

Data for Serbia are presented for period 2009-2014, according to availability in Eurostat database, and calculations were made for that period.

Source: Authors' calculations based on Eurostat data and national statistics of individual countries.

\section{The Analysis of the Link between R\&D Investments and Competitiveness, EU28 and the Case of Serbia}

According to this working paper, the competitiveness implies better position in international trade and export growth. A number of studies that have examined the link between $\mathrm{R} \& \mathrm{D}$ and export, refer only to one causality direction (companies which invest in R\&D have a higher probability of successful export).According to the survey realised in SERC ${ }^{10}$ (Harris R. et al, 2011) R\&D investments in the manufacturing sector have a significantly greater impact on the probability of new products and services export, and improvement of knowledge, which helps to overcome more easily the existing barriers in doing business in the international market. In other business activities, which do not belong to the manufacturing industry, R\&D investments increase the likelihood of innovation, but without significant impact on export.

The following chart presents annual growth in R\&D investments and export of goods and services, in the period 2000-2014. The positive relationship between these two parametres, at the EU28 states level is confirmed by a positive correlation (0.74). The highest annual export growth, was realised by

\footnotetext{
${ }^{10}$ Spatial Economic Research Centre, University of Glasgow.
} 
Lithuania, Slovakia and Bulgaria, while at the same time they realised double digit R\&D investment growth rates.

Figure 3 Exports and R\&D expenditures growth, the period 2000-2014

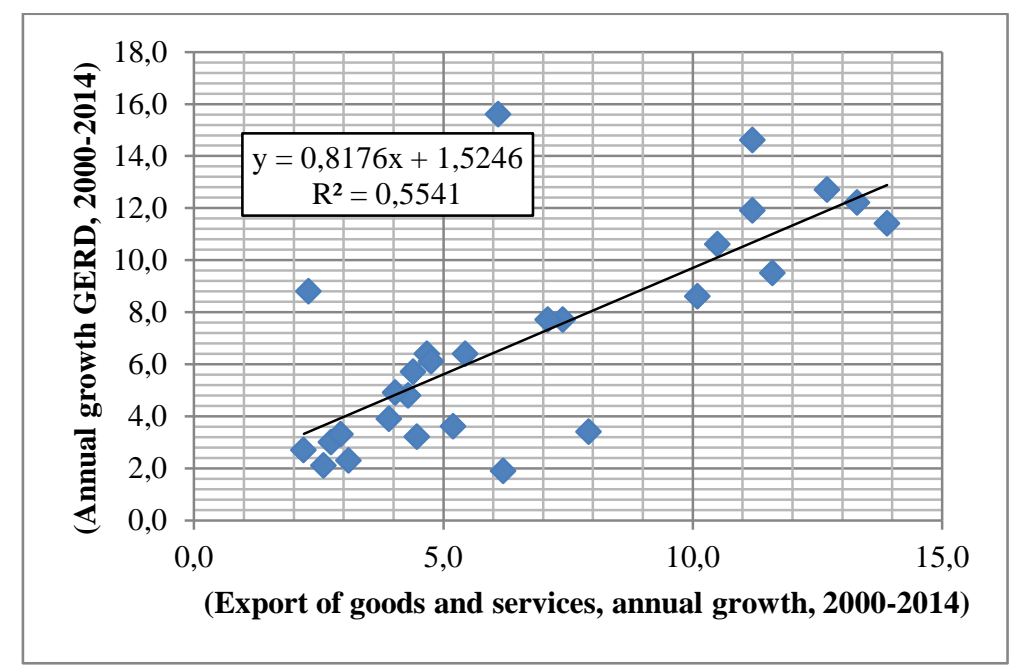

Notes: Annual growth in exports of goods and services is calculated based on the value in EUR million, 2000-2014.

Source: Authors' calculations based on Eurostat data.

\section{The Analysis of the Link between R\&D Expenditures and Economic Growth (EU28 and Serbia case)}

The R\&D intensity, at the example of the EU and Serbia, can be presented by observing the R\&D investment value in relation to GDP. Regression results in OECD research paper (Cheng Si, 2011), have shown that R\&D investment contributes to increasing economic wealth, expressed by GDP value. According to the UN data, in 2013 developed countries invested $69.3 \%$ of the total world's gross R\&D spending, while upper middle-income countries invested $25.8 \%{ }^{11}$ The minimal investments were realised by low-income countries $(0.3 \%$ of total R\&D expenditures in the World). Since 2000, the share of upper middle-income countries has significantly increased from level of $9.7 \%$ in $2000 .{ }^{12}$ According to the UNESCO report, G20 member countries invested even $91.9 \%$ of the global R\&D expenditures in 2013, while OECD countries invested

\footnotetext{
${ }^{11}$ According to the World Bank classification of countries depending on the level of development. Serbia belongs to the group of Upper-middle-income economies.

${ }^{12}$ Southeast European countries have invested $0.1 \%$ of global R\&D expenditures and Central and Eastern Europe countries 4\%.
} 
$66 \%$. Observed by GERD allocations per capita, developed countries invested about 782.1 PPP in R\&D investments in $2013,{ }^{13}$ while South-East European countries invested 42.4 PPP. These data indicate that developed countries invest more in R\&D.

Within the EU28, the old member states (EU15) which allocate a larger amounts for R\&D investments, achieve significantly higher GDP. The following graph shows the participation of EU28 new and old member states, in total EU28 allocations for R\&D. There is also presented the contribution of EU28 new and old member states, within total GDP and EU28 export. New member states achieve the largest share in EU28 export, with only 7\% of the total EU28 GDP , and only 3\% of total R\&D investments at EU28 level.

Figure 4. Old and New EU member states: The share in total R\&D expenditures, GDP and EU28 exports (average for 2000-2014)

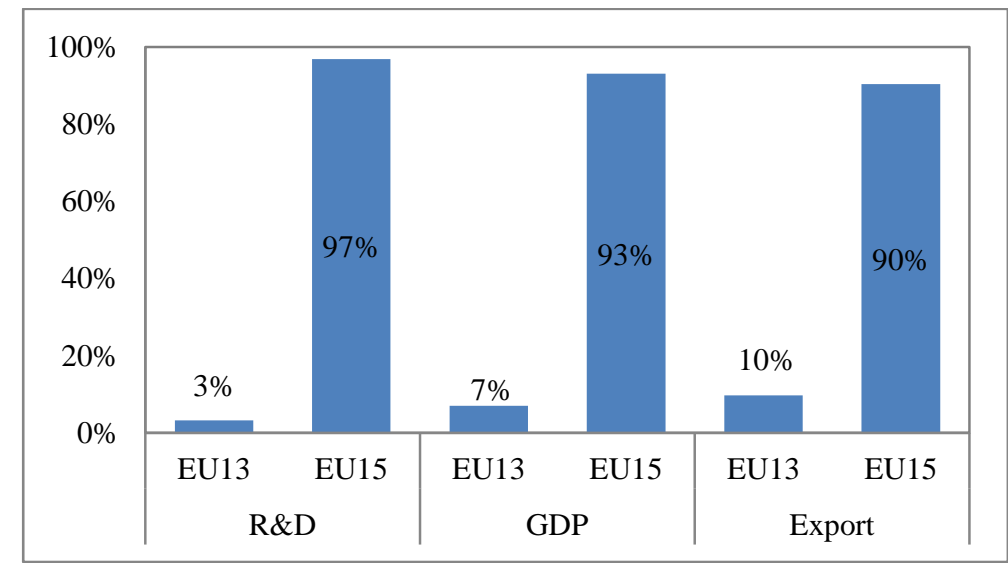

Notes: Share is calculated based on the data: R\&D investments in EUR million, GDP value at current market prices, EUR million, and export in EUR million (at current prices).

Source: Authors' calculations based on Eurostat data.

The following chart presents an annual R\&D investment growth and annual GDP growth in the EU and Serbia, for the period 2000-2014. Each point represents one country. The annual GDP growth, in all countries, was lower compared to the annual R\&D investment growth. Positive relationship between these two indicators, was confirmed in EU countries by the positive correlation (0.7). Within the EU countries, there is a different level of R\&D intensity. Within the old EU member states (EU15), the highest achieved annual R\&D investment growth was recorded in Ireland, Austria and Portugal. Within the

13 Expressed in purchasing power standards, in 2013 the largest level were invested mostly by developed countries of North America about 1,201.8 PPP, while Central and Eastern Europe countries amounted to 145.8 PPP. 
new member states (EU13) much higher R\&D expenditures were recorded, particulary in Malta, Estonia, Bulgaria and Slovakia. According to a survey conducted in 2008 (Verbeek et al., 2008),for the average annual R\&D investment growth and GDP growth similar trends were observed, during period 1995-2005.

Figure 5 GDP growth and R\&D expenditure, 2000-2014

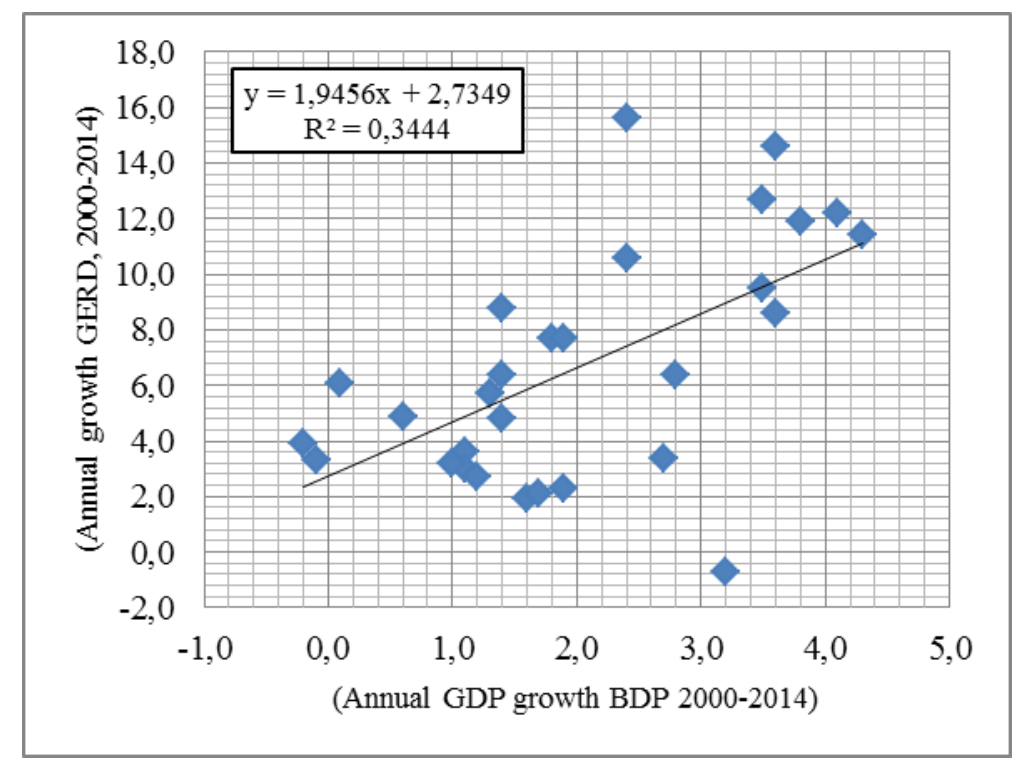

Notes: Annual GDP growth is based on the GDP value, in EUR, market prices, chain linked volumes (2010). Annual GERD growth has been calculated on the basis of data reported in GERD PPP.

Data for Serbia according Eurostat database covering.

Source: Authors’ calculations based on Eurostat data.

\section{Conclusion}

R\&D investment is an important determinant of progress for each national economy. Although, EU in 2002 set target level of R\&D investment to 3\% GDP, in the EU28 the average level of investment of only 2\% GDP was reached. However, EU countries have shown significant differences, not only in the amount of national $R \& D$ investment level, but also in the its structure.A dominant share of the business sector in R\&D financing activities characterises highly developed old member states of EU. On the other hand, the former socialist countries - new member states of the EU, implement at different speed the transition of its R\&D systems, which in time leads to the government sector's share reduction in total R\&D investments. Unlike all observed 
countries, a high share of the higher education sector in the total $R \& D$ expenditures characterises Serbia.

Indicators analysis of the EU and Serbia, in this study has showed that there is positive correlation between the annual growth rate of R\&D investments and annual GDP growth. In addition, research paper has identified the positive correlation between the annual growth rate in R\&D investments and the annual growth rate of exports of goods and services. Serbia lagged the global average share of gross investment in GDP, in the period 2000-2013, while products of lower processing phase and raw materials dominated the export structure. By the results of this work about positively correlated R\&D investments, GDP growth and export growth, one of the key ways of improving the Serbian economy performances is certainly more dynamic R\&D funding financial activities.

The current Strategy to support the development of small and mediumsized enterprises, entrepreneurship and competitiveness recognised the need for more intensive cooperation between science and business in the period 20152020, under the Pillar IV - Strengthening the sustainability and competitiveness of SMEs.

The Strategy of Scientific and Technological Development of Republic of Serbia for the period 2010-2015, also encourages partnerships of the Acedemy with private sector, putting the focus on the protection of intellectual property rights, as well as, special tax incentives for companies investing in $\mathrm{R} \& \mathrm{D}$.

The draft of the new Strategy of Scientific and Technological Development of Republic of Serbia for the period 2016-2020 - Research for Innovation through the proposed strategic goals, the need for ensuring the relevance of science for economic development is once again highlighted, and then encouragement of the business sector to invest in $R \& D$.

\section{References}

Aw Y. B., RobertsM. J., Xu D. Y. (2008). R\&D Investments, Exporting, and the Evolution of Firm Productivity. American Economic Review, Papers and Proceedings, Vol 98, No. 2, pp 451-456.

Chen Xi (2011). R\&D and ICT investment and GDP - A study of OECD countries. Jönköping International Business School.

EUROSTAT, downloaded from: http://ec.europa.eu/eurostat, accessed on 20 January 2016.

Evropski Parlament (2000), preuzeto sa: http://www.europarl.europa.eu/summits/ lis1_en.htm, accessed on 24. January 2016.

Grima, S., Görg, H. and Hanley, A. (2007). R\&D and exporting: A comparison of British and Irish firms. Research Paper Series: Globalisation, Productivity and 
Technology. doi: https://www.nottingham.ac.uk/gep/documents/papers/2007/0718.pdf.

Harris R. and Moffat, J. (2011). R\&D, Innovation and Exporting. SERC Discussion Paper 73. Spatial Economic Research Centre

Havas A., Izsak, K., Markianidou, P. and Radošević, S. (2015). Comparative analysis of policy-mixes of research and innovation policies in Central and Eastern European countries. GRINCOH Working Paper Series, Paper No. 3.12, doi: 10.2139/ssrn.2577569

High Level Expert Group, (2015). COMMITMENT and COHERENCE essential ingredients for success in science and innovation - Ex-Post-Evaluation of the 7th EU Framework Programme (2007-2013).European Commission. Brussels

Lepori, B., Masso, J., Jabłecka, J., Sima, K. and Ukrainski, K. (2009). Comparing the organization of public research funding in central and eastern European countries.Science and Public Policy, 36(9): 667-681, doi 10.3152/030234209X479494;

http://www.ingentaconnect.com/content/beech/spp.

Lucas, Jr., Robert E., (1988). On the Mechanics of Economic Development. Journal of Monetary Economics, 22(4), str. 3-42.

Lykogianni, E., Verbeek A. (2008). A Time Analysis of the Development in National $R \& D$ Intensities and National Public Expenditures on $R \& D$, In relation to (PPCT-M2-2005-0001): Framework Service Contract for Expert Support with the Production and Analysis of R\&D Policy Indicators, Rindicate.

Ministarstvo prosvete, nauke i tehnološkog razvoja (2015), Nacrt Strategije naučnog $i$ tehnološkog razvoja Republike Srbije za period od 2016. do 2020. godine Istraživanje za inovacije. downloaded from http://www.mpn.gov.rs/wpcontent/uploads/2015/08/Strategija-nauka-za-inovacije-17-NOVO.pdf, accessed on 24 January 2016.

OECD/Eurostat (2005).Oslo Manual: Guidelines for Collecting and Interpreting Innovation Data, 3rd Edition, The Measurement of Scientific and Technological Activities, OECD Publishing, Paris.

OECD (2015).Frascati Manual 2015: Guidelines for Collecting and Reporting Data on Research and Experimental Development, The Measurement of Scientific, Technological and Innovation Activities, OECD Publishing, Paris.

PRO-INNO Europe Innovation Index (IUS-2015).

Romer, P. M., (1986). Increasing Returns and Long-Run Growth. Journal of Political Economy, 94(5), pp. 1002-1037.

Romer, P. M. (1990). Endogenous Technological Change.The Journal of Political Economy, Vol. 98, No. 5, Part 2: The Problem of Development: A Conference of the Institute for the Study of Free Enterprise Systems. (Oct., 1990), pp. S71S102.

RZS, downloaded from: http://webrzs.stat.gov.rs/WebSite/public/ReportView.aspx, accessed on 20 January 2016

Solow, R. (1956). A Contribution to the Theory of Economic Growth.The Quarterly Journal of Economics, Vol. 70, No. 1 (Feb., 1956), pp. 65-94. The MIT Press.

UNCTADSTAT, downloaded: http://unctadstat.unctad.org/wds/TableViewer/download Prompt.aspx, accessed on 20 January 2016. 
Vlada Republike Srbije (2010).Strategija naučnog i tehnološkog razvoja Republike Srbije za period od 2010. do 2015. godine (Sl. glasnik RS br. 13/10), preuzeto sa: http://www.gs.gov.rs/lat/strategije-vs.html, pristupljeno: 24.01.2016.

World bank (2013), download from http://www.worldbank.org/content/dam/ Worldbank/document/eca/Western-Balkans-R\%26D-Strategy-Innovation.pdf, accessed on 10 January 2016.

\section{ULAGANJE U ISTRAŽIVANJE I RAZVOJ KAO DETERMINANTA MEĐUNARODNE KONKURENTNOSTI I PRIVREDNOG RASTA U EU28 I SRBIJI}

Apstrakt: Izdvajanje za istraživanje i razvoj (I\&R) predstavlja važan preduslov povećanja konkurentnosti, izvoznih performansi, a samim tim i ekonomskog rasta nacionalnim privredama. Kao primarni faktor privrednog napretka, u savremenim uslovima poslovanja, sve više se nameće znanje, što je prepoznato na globalnom nivou. Jedan od najvažnijih faktora savremenog razvoja je tehnološki razvoj. Profilisanje adekvatne politike izdvajanja za I\&R zahteva analizu odgovarajućih indikatora kojima se ocenjuje dinamika i kvalitet ovih ulaganja kao i pokazatelja koji prate rast i razvoj nacionalnih privreda. U ovom radu je predstavljeno ulaganje u I\&R starih i novih članica EU, kao i u Srbiji, uz sagledavanje jačine korelacije ovog indikatora i privrednog rasta i izvoza. Posebna pažnja je posvećena analizi strukture učešća sektora koji finansiraju I\&R u novim članicama EU, imajući u vidu uticaj intenziteta ulaganja $u$ I\&R na konkurentnost i privredni rast $u$ periodu njihove tranzicije od 2000. godine. Iako su u Srbiji, u periodu od 2000. godine realizovane značajne reforme privrednog ambijenta, sektor I\&R zaostaje za razvijenim zemljama EU. Stoga se ukazuje na značaj profilisanja i realizacije nacionalne politike usmeravanja izdvajanja za I\&R.

Ključne reči: izdvajanje za I\&R, BDP, konkurentnost, izvoz, zemlje u tranziciji, EU, tehnološki razvoj, Srbija

\section{Authors' biographies}

Jelena Vasic defended her Master's thesis at the Faculty of Economics in Belgrade in 2007. She graduated from the Faculty of Economics in Pristina in June 1999 and during the postgraduate course completed AAEN studies. She received a scholarship from the Ministry of Education, the Foundation for the Development of Scientific and Artistic Youth and the Norwegian Embassy as one of the 1.000 best students. Jelena Vasic speaks English. In the period 2001-2003 she worked at the Institute for Foreign Trade. Since June 2003 she has worked at the Chamber of Commerce of Serbia. In October 2014 she was appointed to the position of Senior Advisor for the financial analysis of the Centre for Support of Investments and Public 
Private Partnership. She worked as a consultant and member of the project team on many projects in the country and participated as a co-author in the preparation of numerous studies. She has published a number of papers in economic journals as well as those presented at conferences and meetings of economists.

Nataša Kecman graduated and obtained MSc degree from the Faculty of Economics in Belgrade, where she is a candidate for doctoral dissertation. At the Faculty of Law in Belgrade she completed postgraduate specialist studies on joint stock companies. She has attended numerous national and international training courses related to small and medium sizedenterprises and is an intern at the Permanent Mission of Austria to the EU.

Since 2001 she has been employed at the Yugoslav Chamber of Commerce, where she held a position dealing with the development of international economic cooperation. She transferred to the Serbian Chamber of Commerce in 2003 where she worked on supporting entrepreneurs in applying for specialised international programmes. In the period from 2009 to 2013 she was a national contact person for SMEs to FP7. Since 2015 she has been the Director of the Centre for Services and Mediation Chamber of Commerce of Serbia.

Igor Mladenović is an Associate Professor at the Faculty of Economics. He was elected to the scientific field of Macroeconomics. He is the author of a textbook, two monographs and more than 70 scientific papers. He was involved in 10 international and two national projects. Since 2012 he has been working as an advisor to the President of the Regional Chamber of Commerce Nis and president of the Commercial and Economic Council of the City of $\mathrm{Nis}$ 